\title{
DISTRIBUTION OF ASCORBIC ACID BETWEEN CELLS AND SERUM OF HUMAN BLOOD ${ }^{1}$
}

\author{
By MARTIN HEINEMANN \\ (From the Department of Internal Medicine, Yale University School of Medicine, New Haven)
}

(Received for publication August 2, 1940)

In a previous report (1) the transfer of ascorbic acid from serum to blood cells in vitro was studied with concentrations of ascorbic acid in serum significantly higher than those observed in vivo. This communication deals with the distribution of ascorbic acid between the two phases of human blood when the vitamin is added in amounts above and within physiological limits. The distribution of ascorbic acid under conditions in which the concentrations in cells far exceed those in serum, and the partition of ascorbic acid added to blood under these conditions also are presented.

\section{METHODS}

Ascorbic acid in serum was determined according to the recently described modification (1) of Mindlin and Butler's method (2). Whole blood was analyzed as before, according to the method of Emmerie and van Eekelen (3).

Recently, Butler and Cushman described a new method by which the ascorbic acid concentration of whole blood filtrates is determined colorimetrically (4). Their conclusions confirm our observations (5) that the stores of vitamin $C$ in the body can be estimated better by analyses of whole blood than by analyses of plasma or serum. At the same time, these authors object to the method used in this laboratory because the color developed in filtrates prepared according to the directions of Emmerie and van Eekelen fades rapidly. We agree with Mindlin and Butler (2) and Butler and Cushman (4) that accurate colorimetric determination of ascorbic acid is possible only if conditions can be established in which a stable color is developed.

Figures 1 and 2 of Butler and Cushman (4) are intended to show that in filtrates obtained by Emmerie and van Eekelen's procedure the color fades progressively while it is more stable in filtrates prepared according to their own directions. In these figures, when extrapolated to zero time, $1.16,0.1$ and minus $0.02 \mathrm{mgm}$. per cent by the Butler and Cushman method would correspond to 1.26, 0.18 and $0.18 \mathrm{mgm}$. per cent by the Emmerie and van Eekelen method. Extrapolation of an irregularly progressing curve is highly unsuitable and values thereby

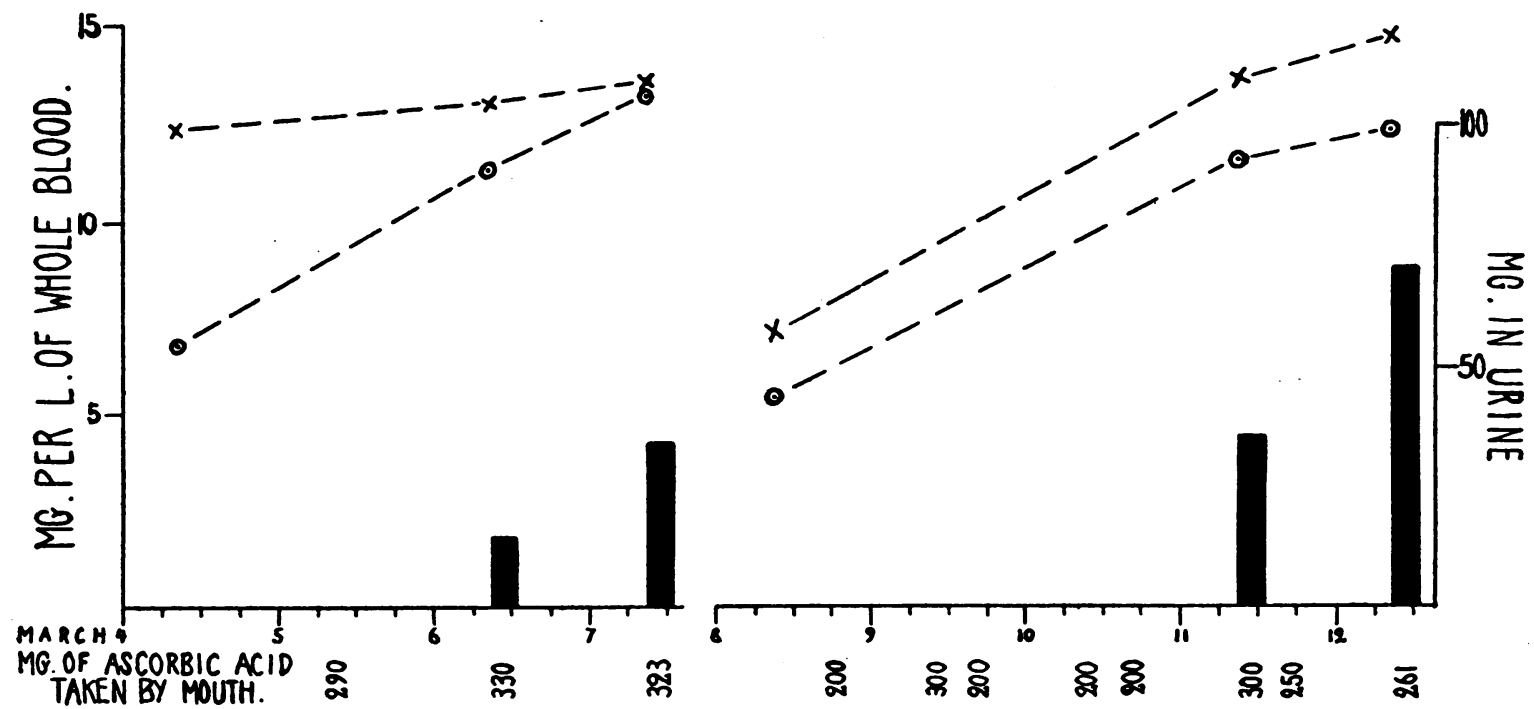

Fig. 1. Correlation Between Urinary Excretion of Ascorbic Acid and Its Concentrations in Whole Blood

Analyses of whole blood by the method of Emmerie and van Eekelen, $X---X$, by the method of Butler and Cushman, $\odot----\odot$.

On March 5, 6, 7, 9, 11 and 12 urinary surplus excretion was determined for 4 hours following the test doses. The amounts excreted are indicated by the solid columns. There was no surplus excretion on March 5 and 9.

1 Aided by a grant from the Markle Foundation. 


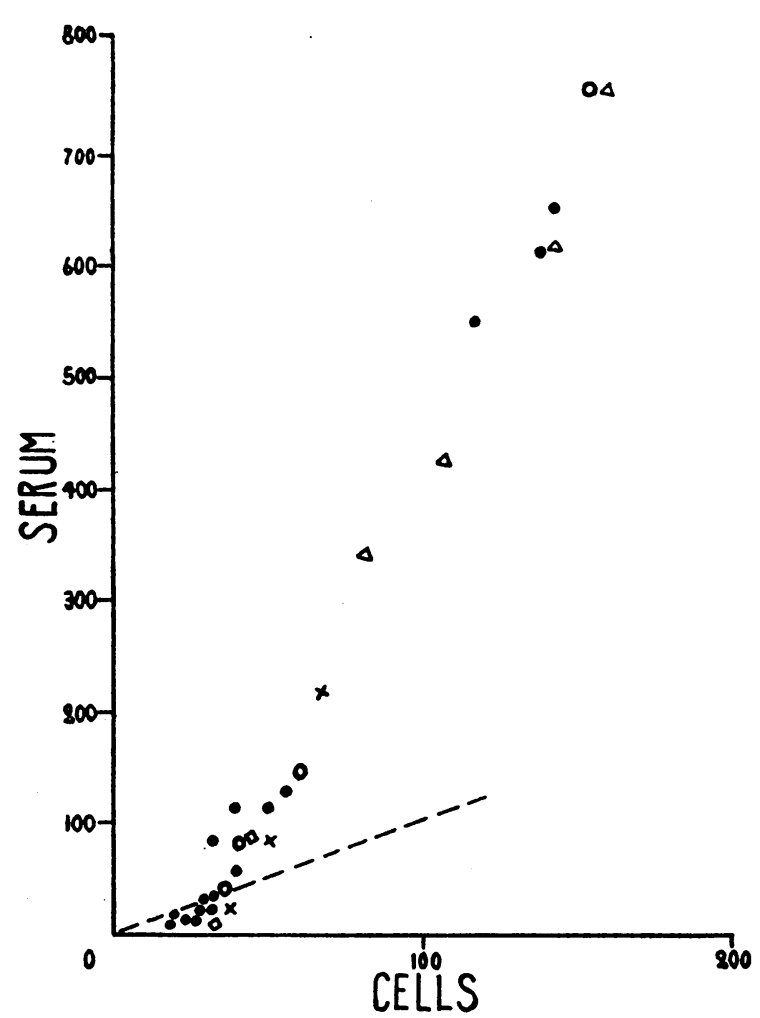

Fig. 2. Distribution of Ascorbic Acid Between Cruls and Serum at Difterent Concentrations of Ascorbic AcID

Concentrations in serum and cells are given as mgm. per liter of water. The water content was not determined but calculated on the basis of average figures of 72.3 per cent for cells and 93.5 per cent for serum, derived from data presented by Eisenman, Mackenzie and Peters (10). The dotted line represents the locus of points on which concentrations in cells and serum would be equal.

obtained are most dubious. Yet, if rapidly fading colors are to be evaluated at all, extrapolation is inevitable.

Figure 1 presents the relationship observed in two experimental subjects of about equal size between urinary excretion of ascorbic acid and whole blood concentrations determined according to both methods. ${ }^{2}$ Emmerie and van Eekelen's procedure was used in its original form, i.e., with titration. Filtrates prepared according to Butler and Cushman's method (4) were measured only with sodium 2, 6-dichlorobenzenoneindophenol as indicator; the methylene blue modification was not employed. The results secured by both methods agree fairly well with each other. Only in one instance-on March 4th, experiment 1-was a difference noted when Butler and Cushman's method gave $6.9 \mathrm{mgm}$. per liter, a value sig-

2 Through the courtesy of Miss M. Cushman and Dr. A. M. Butler, the writer had the privilege of seeing and studying their method in advance of its publication. nificantly lower than $12.5 \mathrm{mgm}$. per liter obtained with Emmerie and van Eekelen's method.

The latter appeared to indicate better the degree of saturation, since after only $290 \mathrm{mgm}$. of ascorbic acid had been taken on the next day, $330 \mathrm{mgm}$. on March 6th caused surplus urinary excretion. With an initial concentration of only $6.9 \mathrm{mgm}$. per liter in whole blood, it is to be expected that a much larger dose of ascorbic acid would be required to produce saturation. On March 7 th and March 11th (Figure 1) when Emmerie and van Eekelen's procedure gave identical results, approximately equal amounts of ascorbic acid were excreted in the urine; the correlation between blood concentrations and amounts excreted in urine is less satisfactory when the values obtained by Butler and Cushman's procedure are accepted.

In the analyses presented in Figure 1, the filtrates prepared according to the directions of Butler and Cushman did not develop stable colors. Expressed in terms of mgm. per liter, the rates of fading were from 0.8 to 1.1, 1.6 to $2.6,1.8$ to $2.5,1.1$ to $1.8,1.6$ to $2.4,1.6$ to 2.3 at 15 to 60 seconds. Plotted on a similar scale, the resulting curves would resemble those obtained by Butler and Cushman in Emmerie and van Eekelen's procedure and represented in their Figure 2. According to Butler and Cushman's criteria, the shape of these curves suggests the presence of interfering colorigenic materials. Our observations differ from their own data and interpretations only quantitatively, proving that their method is open to the same objections voiced against Emmerie and van Eekelen's procedure. This continued fading cannot be attributed to the development of color at an unsuitable acidity. The strength of metaphosphoric acid solutions was well adjusted by titration with $0.1 \mathrm{~N}$ sodium hydroxide. In blanks, stable colors invariably developed with solutions in which the acid was 0.21 to $0.22 \mathrm{~N}$ by titration, using phenolphthalein as indicator. Filtrates from whole blood had consistently the same normality (0.21) when the deproteinization had been carried out with $2 \mathrm{cc}$. of $2.0 \mathrm{~N}$ solution of metaphosphoric acid, 2 cc. of blood and $12 \mathrm{cc}$. of distilled water. The only modification of Butler and Cushman's directions consisted in the use of defibrinated instead of oxalated blood. The former was found to contain approximately 25 per cent less granulocytes than the latter. This difference in white cell count may be significant in certain instances. Observations by Stephens and Hawley (6), Cuttle (7), and Kreuzwendedich von dem Borne (8)-the latter using Emmerie and van Eekelen's method-that granulocytes contained high concentrations of ascorbic acid, were fully confirmed by Butler and Cushman's investigations (4). Since in the present study all measurements by both methods have been conducted on samples of blood treated identically, this loss of granulocytes in the process of defibrination was of no importance.

Two series of data derived incidentally from experiments not intended for this purpose further substantiate the accuracy of Emmerie and van Eekelen's method. Considering the number of manipulations and calculations 
involved, theoretical and observed values agree closely. In the first experiment, the original concentration in serum was 11.7 and that in cells $13.5 \mathrm{mgm}$. of ascorbic acid per liter, respectively; immediately following the addition of ascorbic acid, the serum concentration had increased to $18.6 \mathrm{mgm}$. per liter; after 45 minutes of incubation under the conditions described, this concentration had decreased to $15.5 \mathrm{mgm}$. per liter. With a cell volume of 46 per cent, $3.1 \mathrm{mgm}$. (18.6 minus 15.5 ) removed from serum and transferred to cells would correspond to $6.7 \mathrm{mgm}$. per liter of cells which, plus the original content of 13.5 , would make a total cell concentration of $20.2 \mathrm{mgm}$. per liter. The calculated whole blood concentration was 17.7 ( $460 \mathrm{cc}$. of cells $=9.3 \mathrm{mgm}$. plus $540 \mathrm{cc}$. of serum $=8.4 \mathrm{mgm}$.). By analysis a concentration of $16.8 \mathrm{mgm}$. per liter of whole blood was found. In the second observation, the original concentration in serum was 15.2 , that in cells, $18.3 \mathrm{mgm}$. per liter, respectively; after reducing the ascorbic acid content of serum by a procedure described below, a concentration of $4.0 \mathrm{mgm}$. per liter was found. With a cell volume of 48 per cent, whole blood should contain 10.88 mgm. per liter $(8.78 \mathrm{mgm}$. in $480 \mathrm{cc}$. of cells plus 2.1 $\mathrm{mgm}$. in $520 \mathrm{cc}$. of serum). By analysis $11.1 \mathrm{mgm}$. per liter were found.

\section{EXPERIMENTAL RESULTS}

Collection of blood, control of temperature, addition of crystalline ascorbic acid, continuous agitation of blood in atmospheres of nitrogen or oxygen were all carried out strictly according to the directions recently described (1). "Separated" and "true" sera also were obtained and are referred to in the same manner as before (1). Again, hemolysis and change in cell volume were completely prevented unless, as in one group of experiments, they are expressly mentioned. Investigating "the preservation of ascorbic acid in drawn samples of blood," Kassan and Roe (9) confirmed the necessity of avoiding hemolysis and the comparative stability of ascorbic acid in whole blood. These authors also state that ordinary glass containers promote hemolysis and consequently are not suitable for the preservation of ascorbic acid in blood. In view of this observation it is emphasized that pyrex glass was used throughout all our experiments.

It was previously demonstrated that an atmosphere of nitrogen stabilizes ascorbic acid in whole blood. To confirm the protective action of nitrogen, ascorbic acid was determined at certain intervals not only in true but also in separated sera. That ascorbic acid remains stable in separated sera is conclusively proved by previous experi- ments (Figure 1, $B$ and $C(1)$ ). After many similar observations had attested to the stability of ascorbic acid under these conditions, it seemed justifiable to discontinue determinations of ascorbic acid in "separated sera" in the further course of this investigation.

The technique of studying transfers of ascorbic acid in the experiments presented in this paper was the same throughout: continuous agitation at $37^{\circ} \mathrm{C}$. (or at $7^{\circ} \mathrm{C}$.) in an atmosphere of nitrogen. Crystalline ascorbic acid was dissolved in a small volume of serum and kept at $37^{\circ} \mathrm{C}$. under nitrogen before addition. The amounts transferred to cells were expressed as mgm. per liter of cells and calculated from $\frac{S_{1}-S_{2}}{C V}$, where $S_{1}$ is the concentration in true serum immediately after addition, $S_{2}$ the concentration in true serum after agitation, and $C V$ the cell volume.

As shown before, this method of calculating cell concentrations proved to be reliable when checked by calculating cell concentrations from determinations in whole blood and serum and measurements of cell volumes. The latter procedure was used also for evaluating concentrations originally present in the cells of samples of blood used for further experimentation:

After the addition of ascorbic acid to whole blood its concentration was determined in samples of true serum removed immediately, after 30 minutes, and after about 45 minutes. In agreement with the previous report, transfers were invariably completed within 30 minutes. The results obtained after these intervals, therefore, should not and actually did not differ. Whenever they do, either a leakage in the system through which nitrogen is conducted or imperfectly cleaned glassware must be suspected. For the evaluation of observations resulting from this experimental technique, the prevention of oxidative destruction of ascorbic acid by nitrogen acquires intrinsic significance. Anticipating experimental data presented below, the protective action of nitrogen was evident in all the experiments in which no changes in ascorbic acid concentrations occurred in true sera separated from incubated whole blood before and after the aforementioned intervals. Furthermore, when ascorbic acid was added to samples of the same blood, but with different cell volumes (obtained by removing varying volumes of serum), the decrease in true serum varied directly with the number of cells. If ascorbic acid 
were destroyed under the experimental conditions, the smallest amounts would be lost in the presence of the largest number of cells, the protective action of which upon ascorbic acid in serum is generally recognized.

\section{A. Rate of distribution of ascorbic acid between serum and cells following its addition to defibrinated blood ${ }^{3}$}

Figure 2 represents the distribution of ascorbic acid between the two phases of blood following the addition of widely varying amounts of the vitamin. In this figure, squares, triangles, open circles and crosses depict four experiments in which different amounts of ascorbic acid were added to samples of the same blood; solid circles indicate single observations. The data of both groups demonstrate alike that the amounts of ascorbic acid transferred to cells decrease as the concentrations in serum diminish.

\section{B. Lack of transfer of ascorbic acid from cells to serum}

A patient with peptic ulcer and vitamin $C$ depletion subsequent to dietary treatment was found to have concentrations of ascorbic acid in whole blood of 4.6 , in serum of only $0.61 \mathrm{mgm}$. per liter. At a cell volume of 41 per cent, the concentration of ascorbic acid in cells amounted to $10.3 \mathrm{mgm}$. per liter. These concentrations did not change after 2 hours of incubation under the usual conditions. The concentration in true serum remained constant also during 50 minutes following the addition of small amounts of ascorbic acid by which the concentration in serum was increased to $7.2 \mathrm{mgm}$. per liter.

Conditions similar to those of this observation were duplicated experimentally in the following way: From freshly drawn defibrinated blood, serum and cells were separated by centrifuging. The cells were kept in a tightly stoppered container at about $23^{\circ} \mathrm{C}$. while the serum was treated with a wet stream of oxygen at $37^{\circ} \mathrm{C}$. for $1 \frac{1}{2}$ to 2 hours, which almost completely destroyed its ascorbic acid. Consequently, serum and cells were placed separately in an atmosphere of nitrogen at $37^{\circ} \mathrm{C}$. for 30 minutes before being

3 Human blood was used invariably. remixed. In the following presentation of experminents where this technique was employed, serum treated with oxygen, and subsequently with nitrogen, will be referred to as " prepared serum ;" separated cells, kept at room temperature and treated with nitrogen for half an hour, as "prepared cells."

It will be noted that concentrations in serum of blood composed of "prepared serum" and "prepared cells" were low, but not zero. This was due to the impossibility of completely removing the original serum containing ascorbic acid from "prepared cells." This amount of ascorbic acid in the serum of "prepared cells" became even more inconvenient in the experiments in which it was increased by addition of ascorbic acid. As will be shown, such sera could be diluted to satisfactorily low concentrations by using $20 \mathrm{cc}$. each of "prepared serum" (without ascorbic acid) and "prepared cells."

In three such experiments, concentrations of ascorbic acid in true serum determined immediately and at intervals after mixing both phases of blood remained unchanged during 1 hour. The corresponding concentrations in serum and cells were 3.2 and 26.4, 4.3 and 20.0, 1.0 and 19.6 mgm. of ascorbic acid per liter of water, respectively.

In three more experiments, "prepared serum" was obtained from one portion of blood. Another portion was incubated following addition of ascorbic acid and the amounts transferred to cells were calculated in the manner described above. These amounts plus the ones originally present express the total concentration in cells. After removing the serum from this incubated whole blood as completely as possible by centrifugation, the remaining cells were treated with nitrogen for 30 minutes. In this way, "prepared cells" containing $37.1,144.3$ and $117.4 \mathrm{mgm}$. of ascorbic acid per liter of water, respectively, were remixed with corresponding "prepared sera" containing $11.8,35.7$ and $36.0 \mathrm{mgm}$. per liter of water, respectively. In no instance was any change in the concentrations in true sera observed during 70 minutes of continuous agitation at $37^{\circ} \mathrm{C}$. under nitrogen. In three experiments carried out identically, except that the temperature was $7^{\circ} \mathrm{C}$., concentrations in true sera likewise remained stable. 


\section{Lack of transfer of ascorbic acid from serim to cells following the addition of this substance}

Incidentally, the distribution of added ascorbic acid was investigated in the blood of a patient with secondary anemia who was markedly depleted as the result of inadequate diet. The original concentrations were $4.4 \mathrm{mgm}$. per liter of whole blood, $1.0 \mathrm{mgm}$. per liter of serum; cell volume was 31 per cent, the concentration of ascorbic acid per liter of cells $11.97 \mathrm{mgm}$., or $16.6 \mathrm{mgm}$. per liter of water in cells, against $1.07 \mathrm{mgm}$. per liter of water in serum. In experiments carried out in duplicate no uptake of ascorbic acid could be detected during 1 hour following the addition of ascorbic acid so as to increase the serum concentrations to 57.0 and $61.0 \mathrm{mgm}$. per liter of water, respectively.

This incidental observation was imitated by using blood composed of "prepared serum" and "prepared cells." Ascorbic acid was added to samples of this blood (a) immediately, (b) 1 hour and $(c) 2$ hours after its two components had been re-mixed. Determining the amounts transferred to the cells in the course of 1 hour, the corresponding changes in serum concentrations were (a) 73.3 to 65.3 , (b) 59.0 to 54.4 and (c) 68.9 to $68.0 \mathrm{mgm}$. per liter, respectively. In another experiment, one part of serum was transformed into "prepared serum" while the other part, kept under nitrogen, maintained its original concentration of $8.5 \mathrm{mgm}$. of ascorbic acid per liter. Consequently, "prepared cells" from the same blood were added to these sera and gently agitated under the usual conditions. After 2 hours ascorbic acid was added to each blood. In the blood with serum, the ascorbic acid of which had been preserved, a transfer of 8.3 (63.3 to $55.0) \mathrm{mgm}$. $=20.2 \mathrm{mgm}$. per liter of cells was noted after 60 and also after 105 minutes; cells in contact with "prepared serum" for 2 hours prior to the addition of ascorbic acid took up no ascorbic acid; the concentration in the serum remained $48.3 \mathrm{mgm}$. per liter of serum throughout. These results must be presented with certain reserve since cell volumes did not remain constant, changing in the experiments from 40 to 41.5 per cent, 40 to 41.8 per cent, and 40 to 41 per cent, respectively. The increases in cell volume, significant because they never occurred in the experiments hitherto described, appear to be due to changes in serum rather than in cells. They occurred in "prepared serum" as well as in serum treated with nitrogen only, and were independent of the addition of ascorbic acid; they could not be prevented by using cells separated from samples of blood drawn freshly from the same subject after the preparation of the sera was completed.

\section{DISCUSSION}

The data presented in Figure 2 show that the amounts of ascorbic acid transferred from serum to cells, following its addition to blood, bear a direct relation to its concentrations in serum. The ratios of distribution between cells and serum are about the same in experiments in which different concentrations of ascorbic acid are added to samples of the same blood as they are when ascorbic acid is added to various bloods. At concentrations of ascorbic acid higher than any that occur in vivo, serum always contains more than cells. The ratio, ascorbic acid of serum: ascorbic acid of cells, declines from approximately 4.75 at serum concentrations of 600 to $750 \mathrm{mgm}$. per liter to 2.5 at concentrations of 100 to $150 \mathrm{mgm}$. per liter and to 1.5 at a concentration of $50 \mathrm{mgm}$. per liter. It approaches unity, as previous experiments suggested (1) at about $35 \mathrm{mgm}$. of ascorbic acid per liter of water in serum.

Previously, the necessity of imitating physiological conditions was demonstrated with respect to temperature and to the avoidance of sedimentation of blood (1). Yet, in spite of maintaining proper temperature and providing for contact between all the cells and serum by continued agitation, the distribution ratios differed from those observed in vivo and it may now be concluded that this was due to artificially high concentrations. When these also conformed to physiological limits (Figure 2, below dotted line), however, the ratios in vitro corresponded to those established in vivo.

Below $35 \mathrm{mgm}$. per liter of water the concentrations in cells exceed those in serum. That reversal of the ratio appears at about this point is confirmed by the experiment presented in Table I in which different quantities of ascorbic acid were added to samples of the same blood to yield vari- 
TABLE I

Distribution of different concentrations of ascorbic acid added to sample of the same blood

\begin{tabular}{l|c|c|c}
\hline \hline & Serum & Cells & Quotient $\frac{\text { Serum }}{\text { Cells }}$ \\
\hline & $\begin{array}{c}\text { mgm. per liter } \\
\text { of water }\end{array}$ & $\begin{array}{c}\text { mgm. per liter } \\
\text { of water }\end{array}$ & \\
Original & 11.8 & 19.0 & \\
After addition & 18.2 & 20.0 & 0.91 \\
After addition & 26.7 & 29.0 & 0.92 \\
After addition & 38.0 & 32.1 & 1.18 \\
\hline
\end{tabular}

ous concentrations in the region of $35 \mathrm{mgm}$. per liter.

These observations in vitro agree well with results of analyses of serum and cells of freshly drawn blood reported earlier (5). In thirty instances without exception more ascorbic acid was found in cells than in serum. The differences, illustrated in Figure 3 of that communication, would be even greater if concentrations were recorded in terms of mgm. per liter of water instead of mgm. per liter of total volume. In vitro as well as in vivo, at concentrations within the physiological range, cells withdraw the vitamin from serum beyond the point of equal distribution. Above the critical concentration of $35 \mathrm{mgm}$. per liter, however, which is far higher than concentrations encountered in circulating blood, the amounts transferred are so small that the concentrations ultimately attained are always lower in cells than in serum. This inversion of distribution ratios with changing concentrations seems to prove quite conclusively that simple diffusion alone cannot control the partition of ascorbic acid between the two phases of blood.

In freshly drawn blood, concentrations of ascorbic acid never exceed 35 , rarely $20 \mathrm{mgm}$. per liter, unless they are intentionally raised for experimental purposes. In vivo, as stated before, distribution ratios, expressed as concentration in serum: concentration in cells, are always less than 1.0. Ratios greater than 1.0 may be produced by the administration of large doses of ascorbic acid; but only transiently, because of the transfer to cells and the rapid elimination by the kidneys which sets in when the concentration in the serum surpasses about 14 mgm. per liter.

If a curve were drawn to represent the trend of all the observations in Figure 2, it would not be possible to determine with any certainty the trend of distribution ratios at high concentrations. In the experiments recorded in this figure the maximum concentration attained in cells, when the concentration in serum had been raised to 750 mgm. per liter of water, was approximately 160 mgm. per liter of water. No further increase in concentrations in the cells could be detected when the concentrations in serum were increased to about $900 \mathrm{mgm}$. However, at these concentrations filtrates must be diluted about 100 times for analysis. The error of the method, therefore, prohibits exact estimations. For this reason it is impossible to decide whether $160 \mathrm{mgm}$. per liter of water actually represent the maximal load which cells will assume. The general trend of the observations does suggest, however, that the concentrations in cells approach a limit.

As concentrations diminish, the curve describing the distribution of points seems to approach the origin. This is substantiated by observations of Butler and Cushman (4), who reported minimal concentrations of ascorbic acid both in cells and serum in patients with scurvy or prolonged vitamin C deficiency. Saturation is characterized by high concentrations of ascorbic acid in both phases of blood (5) ; scurvy by its almost complete absence in serum as well as in cells (4).

Passage of ascorbic acid from cells to serum was not observed under conditions in which its concentration was definitely higher in cells than in serum. Transfers from serum to cells appeared to be associated with some metabolic activity of the cells, since they took place at $37^{\circ} \mathrm{C}$., but not at $7^{\circ} \mathrm{C}$. But variations of temperature or increasing concentrations in cells to values as high as $140 \mathrm{mgm}$. per liter of water had no power to move the vitamin in the other direction, from cells to serum. Ascorbic acid, therefore, seems to form a combination with some substance or substances within the cells from which it cannot be released by any measures thus far discovered. A similar conclusion has been reached by Reedman and McHenry (11), Fujita and Ebihara (12) and Holtz and Walter (13) concerning the state of the vitamin in plant and animal tissues. These authors assume that it is combined with protein. Levine, Marples and Gordon (14), from studies on infants have concluded that the metabolism of aromatic amino acids depends upon the quantities of ascorbic acid stored in the body. 
The avidity of cells for ascorbic acid and their stubborn retention of the substance in vitro conform well to what is known of their behavior in the body. Individuals have tolerated deprivation of vitamin C for 42 (4), 94 (15) and 160 (16) days without the appearance of any signs of scurvy. Butler and Cushman (4) noted that the concentration of ascorbic acid in the serum diminished rapidly early in the course of vitamin $C$ deprivation, while the concentrations in the cells decreased considerably later, and gradually. The granulocytes-and possibly platelets-retained ascorbic acid longer than red cells. If ascorbic acid cannot pass from cells to serum this would indicate that ascorbic acid is metabolized or destroyed more rapidly in erythrocytes than in granulocytes.

The principles that govern the distribution and transfer of ascorbic acid in blood provide an adequate explanation for the fact already established, that the amounts of ascorbic acid in the body can be better estimated from analyses of whole blood than from analyses of serum $(4,5)$. Concentrations in cells cannot be neglected. In Table IV of Butler and Cushman's (4) paper there are five instances in which, without scurvy, plasma was free from ascorbic acid. Yu (18) reported that with equally low vitamin $C$ concentrations (less than $2 \mathrm{mgm}$. per liter of plasma) some persons had manifest scurvy while others were apparently healthy. Under similar circumstances, in our experience, an explanation for the discrepancy has been found by analyses of whole blood.

Passage of ascorbic acid from serum to cells was lacking in a blood with an abnormally low serum concentration. A similar observation was omitted from our previous report (1) because it was made at the very beginning of this investigation when the experimental technique was not yet perfected. Transfer of ascorbic acid did not take place either in blood, in the serum of which it had been destroyed experimentally. Cells were found to lose the ability to take up ascorbic acid not immediately after being placed in "prepared serum" but only progressively in the course of 2 hours. Except for this observation that the reaction is not an instantaneous one, the effect of low concentrations of ascorbic acid in the environment upon the membrane, metabolic activity or physicochemical status of cells cannot even be intimated. It may be correlated with observations by van Eekelen (15) who found that the amounts of vitamin $\mathrm{C}$ daily metabolized diminished as the stores in the body decreased. Since concentrations diminish more rapidly in serum than in cells, and since low serum concentrations impair the ability of cells to take up ascorbic acid, it does not seem inconceivable that the metabolism of ascorbic acid in tissue cells like that in blood cells depends upon concentrations in serum.*

In the example just discussed, the influence of serum upon cell function was related to concentrations of ascorbic acid in the former; the effect of incubated serum upon cell volumes cannot be correlated with any known factor.

\section{SUMMARY AND CONCLUSIONS}

(1) Amounts of ascorbic acid transferred from serum to cells were estimated from concentrations in the former removed from whole blood immediately and at certain intervals after the addition of ascorbic acid.

(2) As concentrations in serum decrease, the amounts transferred to and the concentrations attained in cells also diminish.

(3) Distribution ratios are greater than unity above serum concentrations of about $35 \mathrm{mgm}$. per liter of water, smaller than unity below this concentration. The partition of ascorbic acid in both phases of blood is not governed by simple diffusion.

(4) Ascorbic acid is not transferred from cells to serum when the former contain concentrations significantly higher than the latter, either at $37^{\circ}$ C. or at $7^{\circ} \mathrm{C}$. Ascorbic acid appears to be irreversibly combined with some intracellular substance or substances.

(5) The magnitude of concentrations of ascorbic acid in serum seems to affect the cellular functions involved in the mechanism of transfer of added ascorbic acid. No uptake occurred when cells, prior to addition, were kept in serum with low concentrations of ascorbic acid.

\footnotetext{
4 Differences in the rate of uptake by different tissues (19) or with regard to dehydroascorbic acid and its reduced form (20) would not contradict this inference.
} 


\section{BIBLIOGRAPHY}

1. Heinemann, M., and Hald, P. M., Factors that influence the passage of ascorbic acid from serum to cells in human blood. J. Clin. Invest., 1940, 19, 469.

2. Mindlin, R. L., and Butler, A. M., The determination of ascorbic acid in plasma; a macromethod and micromethod. J. Biol. Chem., 1938, 122, 673.

3. Emmerie, A., and van Eekelen, M., The chemical determination of vitamin $C$ with removal of interfering reducing and coloured substances. Biochem. J., 1934, 28, 1153.

4. Butler, A. M., and Cushman, M., Distribution of ascorbic acid in the blood and its nutritional significance. J. Clin. Invest., 1940, 19, 459.

5. Heinemann, M., The distribution of ascorbic acid between cells and serum in relation to its urinary excretion. J. Clin. Invest., 1938, 17, 751.

6. Stephens, D. T., and Hawley, E. E., The partition of reduced ascorbic acid in blood. J. Biol. Chem., 1936, 115, 653.

7. Cuttle, T. D., Observations on the relation of leucocytosis to ascorbic acid requirements. Quart. J. Med., 1938, 7, 575.

8. Kreuzwendedich von dem Borne, G. A., Vitamine $\mathrm{C}$-bepalingen bij gezonden en bij zieken met chronische polyarthritis, scorbuut en leucaemie. Nederl. Tijdschr. v. Geneesk., 1939, 83, 5265.

9. Kassan, R. J., and Roe, J. H., The preservation of ascorbic acid in drawn samples of blood. J. Biol. Chem., 1940, 133, 579.

10. Eisenman, A. J., Mackenzie, L. B., and Peters, J. P., Protein and water of serum and cells of human blood, with a note on the measurement of red blood cell volume. J. Biol. Chem., 1936, 116, 33.

11. Reedman, E. J., and McHenry, E. W., Combined ascorbic acid in plant tissues. Biochem. J., 1938, $32,85$.

12. Fujita, A., and Ebihara, T., Ueber die gebundene Ascorbinsäure in pflanzlichen Geweben. Biochem. Ztschr., 1939, 301, 229.

13. Holtz, P., and Walter, H., Ueber die gebundene Ascorbinsäure tierischer Gewebe. Hoppe-Seyler's Ztschr. physiol. Chem., 1940, 263, 187.

14. Levine, S. Z., Marples, E., and Gordon, H. H., A defect in the metabolism of aromatic amino acids in premature infants: the rôle of vitamin C. Science, 1939, 90, 620.

15. van Eekelen, M., On the amount of ascorbic acid in blood and urine. The daily human requirements for ascorbic acid. Biochem. J., 1936, 30, 2291.

16. Rietschel, H., and Schick, H., 160 Tage C-vitaminfreie Ernährung. Beobachtungen am Menschen. Klin. Wchnschr., 1939, 18, 1285.

17. van Eekelen, M., and Heinemann, M., Critical remarks on the determination of urinary excretion of ascorbic acid. J. Clin. Invest., 1938, 17, 293.

18. $Y u, T$. F., Blood vitamin $C$ content of Chinese in Peiping during the winter of 1938 to 1939 . Chinese M. J., 1939, 56, 334.

19. Hou, H. C., Fixation of ascorbic acid by tissues. Proc. Soc. Exper. Biol. and Med., 1936, 34, 833.

20. Fox, F. W., and Levy, L. F., Experiments confirming the antiscorbutic activity of dehydroascorbic acid and a study of its storage and that of ascorbic acid by the guinea pig at different levels of intake. Biochem. J., 1936, 30, 211. 